\title{
Assessment of Leadership Style and Safety in Oil and Gas Servicing Firms in Port Harcourt Metropolis, Nigeria
}

\author{
Onuoha $\mathrm{F}^{1}$, Oyegun $\mathrm{CU}^{2}$, Ugbebor $\mathrm{JN}^{3}$
}

${ }^{1}$ Centre for Occupational Health, Safety and Environment (COHSE), University of Port-Harcourt, Choba, Rivers State, Nigeria, ${ }^{2}$ Department of Geography and Environmental Management, Faculty of Social Sciences, University of Port-Harcourt, Choba, Rivers State, Nigeria, ${ }^{3}$ Institute of Petroleum engineering studies, University of Port-Harcourt, Choba, Rivers State, Nigeria

\section{ABSTRACT}

Introduction: Safety leadership is the process of interaction between leaders and followers, through which leaders exert their influence on followers to achieve organizational safety goals under the circumstances of organizational and individual factors.

Objective: This study was aimed to assess leadership style and safety in oil and gas servicing firms in Portharcourt, Nigeria.

Methods: A cross-sectional study was conducted among the junior-staff of the oil servicing firms. The Taro Yamane equation was used to generate appropriate sample size of 389 respondents from 16240 workers. Data analyses was done using analysis of variance (ANOVA).

Results: It was established that $230(59 \%)$ respondents agreed that, leaders checked staff work on a regular basis to assess their progress and learning. Many respondents (62\%) averred that leaders didn't gave any incentives for extra work. Also, 338 (87\%) respondents adduced that changes in policies were discussed with workers before they were carried out but, the input of the workers were not required, neither staff were expected to be innovative as opined by $76 \%$ respondents and leadership emphasis on the importance of quality was sustained. Albeit, workers weren't allowed to contribute to control standards based on perception of problems. The characteristics of leadership displayed in the companies imply the transactional type. This was because the rapport between workers and leaders wasn't cordial.

Conclusion: The study therefore strongly recommends a review of the leadership style adopted for oil and gas workers in the area, while improving on the worker/leader relationships.

Key words: Assessment, Risk, Safety, Transformational-leadership.

\section{Introduction}

Safety leadership is a sub-system of organizational leadership. ${ }^{1}$ Safety leadership is the process of interaction between leaders and followers, through

DOI: https://doi.org/10.3126/ijosh.v11i1.33417

Date of submission: 15.12 .2020

Date of acceptance: 15.02 .2021

\section{Corresponding Author}

Foreman, Onuoha, MSc

Centre for Occupational Health, Safety and Environment (COHSE)

University of Port-Harcourt, Choba, Rivers State, Nigeria.

Tel: +2348119222555,

E-mail: foremanonuoha77@gmail.com

ORCID ID: https://orcid.org/0000-0002-2244-4214 which leaders exert their influence on followers to achieve organizational safety goals under the circumstances of organizational and individual factors. ${ }^{2}$ This interaction among the leaders and the led presents the privilege for sharing valuable insights on issues related to work place safety, and the oil and gas industry is not an exemption to this. ${ }^{1,3}$ An inquiry into relationships between senior managers' perceived leadership style and the safety performance of units, showed that leadership behaviours like intellectual stimulation, idealized consideration and contingent reward were significantly connected to lower accident

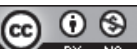

This journal is licensed under a Creative Commons AttributionNon Commercial 4.0 International License. 
rates. ${ }^{3}$ Broadly two leadership styles have been established in the literature and these are either the caring or the controlling styles of leadership. ${ }^{4,5}$ Whereas the caring leadership style encapsulates providing help when needed, establishing harmonious relationship with subordinates, the controlling type is concerned with setting up organisational goals, establishing and maintaining performance levels. ${ }^{6}$

A study in the United-Kingdom with 200 oil firms' managers who superintended about 157 production platforms and drilling rigs recognised four important safety leadership issues. ${ }^{7}$ These issues were (a) visibility at the worksite and leading by example, (b) developing open, honest and trusting relationships with the workforce, (c) workforce involvement and empowerment in planning and decision-making, thereby increasing workforce ownership and responsibility of safety performance, and (d) being proactive about safety. ${ }^{7}$

Safety climate describes employees' perception about safety in their organization, and how the perceptions they form guide their safety-related behaviours. ${ }^{8,9}$ Studies have revealed safety climate to be fundamental in improving workplace practical safety indicators since it represents employees perceptions of safetyrelated policies, procedures and practices prevalent in workplaces. ${ }^{1,7}$ Therefore, positive safety climate is a sine-qua-non for employees of organizations to carry out their job functions and roles safely. 2,10

In examining safety behaviours, two distinct components whose nomenclatures are based on the job performance are widely considered. They are, safety compliance and safety participation. ${ }^{11}$ Safety compliance and safety participation have been greatly researched as core components of safety behaviours. ${ }^{2}$ However, proposes the inclusion of risky behaviour as another component of safety behaviours. Though this component has been earlier proposed, it yet lacks some empirical prominence in safety management literature. ${ }^{12,13}$

Also, proposed is threefold job performance structure, which can fit into safety behaviours study. ${ }^{5}$ Risky behaviours can cause adverse consequences in the workplace. ${ }^{14,15}$ However, the submission on latent errors clarifies the understanding that risky behaviour is a nonconformity with standard organizational practices, processes and beliefs that may not necessarily cause instantaneous consequences. ${ }^{14}$ Succinctly put, based on the submissions of previous studies, the relationships between safety climate and safety behaviours have been positive..$^{15}$ Nevertheless, leadership is a critical socio-psychological organizational factor capable of determining and/or explaining safety outcomes.,15 Leadership is the single most critical factor affecting organizational safety performance. ${ }^{16}$ It is also noted that leadership characteristics that support safety is capable of shaping subordinates' perception of risk. ${ }^{17}$

Interestingly, a search of the leadership and safety management literature points to a good number of studies that have been done across diverse work settings and socio-demographic milieus on the positive relationship between leadership and safety behaviours. ${ }^{4,18}$ However, the number of studies that examined leadership as an antecedent of safety climate, and in relation to safety behaviours are quite scant, indicating paucity. ${ }^{5,7}$

There appears to be a great disconnect between leaders and workers at the oil and gas servicing firms in Portharcourt. Reasons include, available and cheap labour and poorly regulated labour and lack of laws. ${ }^{19}$ Available literature showed studies conducted on leadership and safety for the oil and gas industry. ${ }^{20,21,22}$ Nonetheless, there are still glaring fragmentations in most of these contributions, thus justifying the need for additional research. For instance, none of these studies explicitly focussed on identifying leadership style that is the most precursor of safety in Nigerian oil and gas operations. Majority of the available studies focussed on safety leadership in the United Kingdom, United States and Norwegian oil and gas industry with very scant studies in Nigeria. These justifies the current attempt, wherein the aim is to assess leadership style and safety in oil and gas servicing firms in Portharcourt metropolis Nigeria.

\section{Materials and methods}

The study was conducted in Portharcourt, Nigeria as there were many oil installations in this area. The research design was cross-sectional type and the target population were the junior staffs (workers with less than or equal to 10 years' experience in the sector) of the oil and gas servicing firms in Portharcourt. Purposive sampling technique was used to select 81 companies from 102 companies based on the following assumptions: companies have proper work structure and have operated more than 25 years. The Taro Yamane equation was used to calculate appropriate 
sample size of respondents from 16240 workers for the study (see equation 1) and a sample of 389 was derived. Data was collected by administering copies of questionnaire to respondents. Questionnaire was put through face and content validation by experts and reliability achieved via test retest method.

$n=N /\left\{1+N\left(e^{2}\right)\right\}$ eq 1

where $\mathrm{n}=$ the sample size

$\mathrm{N}=$ the total population size

e = sampling error (in this case 0.05 )

$1=$ constant

The data obtained through the questionnaire survey were presented in Tables and data analyses, was done using analysis of variance (ANOVA).

\section{Results}

The results for this study are presented in two Tables. Table one presented the perception of the respondents, while table two displayed the hypothesis testing for the study. Of the total participants, 230 (59\%) respondents agreed that, leader checked staff work on a regular basis to assess their progress and learning, while, $159(41 \%)$ of the respondents disagreed. This was an indication that there was adequate monitoring of the work process in the companies. More than half of respondents (51\%) disagreed that leaders hardly appointed staff into task groups to action policies affecting them (Table 1). Three- fourth of the respondents $(78 \%)$ supported on leaders not providing staff with clear responsibilities and allowing them to decide how to accomplish them. The workers were also not allowed to use or apply their individual intuition. Furthermore, 307 (79\%) respondents' opined that leaders make sure staff were aware of, and understood, all organisation policies and procedures in the firms. Therefore, the accidents that occurred in the oil and gas servicing firms might be related to workers not allowing to change contingencies when there was urgency, or the emotional intelligence of the workers had been affected using poor leadership styles.

Similarly, 241 (62\%) respondents identified their achievements were not recognized with encouragement and support. Most of the respondents (87\%) agreed changes in policies were discussed with them before they were carried out. However, the input of the workers meant nothing as most of those discussions were held for communication and application purposes. It also showed $66(17 \%)$ respondents agreed tasks were demonstrated by leaders before workers started their work, while 333 (83\%) respondents disagreed. Albeit, $86(22 \%)$ respondents agreed leaders avoided making judgements or premature evaluation of ideas or suggestions, while 303 (78\%) respondents disagreed. Nevertheless, 261 (67\%) respondents opined workers were not allowed to think long term along with company's prospects (Table 1).

Almost one-fourth (25\%) of respondents thought leadership emphasized on the importance of quality but did not allow staff to establish the control standards. Respondents perception regarding how leader provided staff with the time and resources to pursue developmental objectives was agreed by $17 \%$ of respondents. Finally, of the three leadership styles interrogated in this study 268 (69\%) respondents opined that the leadership style applicable in their companies was the transactional type, while only 121 $(31 \%)$ respondents suggested that the transformational type of leadership was applicable in their companies. However, the laissez-faire type of leadership style was not used in any company. However, the ANOVA test showed no significant variation in the leadership styles in the oil and gas servicing companies in the study area at $\mathrm{P}>0.05$ (Table 2).

Table 1: Distribution of respondents by their perception in leadership style and safety in oil and gas servicing firms

\begin{tabular}{lccccc}
\hline Perceptions & $\begin{array}{c}\text { Strongly } \\
\text { agreed } \\
(\%)\end{array}$ & $\begin{array}{c}\text { Agreed } \\
(\%)\end{array}$ & $\begin{array}{c}\text { Disagreed } \\
(\%)\end{array}$ & $\begin{array}{c}\text { Strongly } \\
\text { disagreed } \\
(\%)\end{array}$ & Total (\%) \\
\hline $\begin{array}{l}\text { My leader checks staff work on a regular basis to } \\
\text { assess their progress and learning }\end{array}$ & $83(21)$ & $149(38)$ & 89 & $69(18)$ & $389(100)$ \\
$\begin{array}{l}\text { My leader always appoints staff into task groups to } \\
\text { action policies affecting them }\end{array}$ & $51(13)$ & $132(34)$ & $107(28)$ & $99(25)$ & $389(100)$ \\
$\begin{array}{l}\text { My leader provides staff with clear responsibilities } \\
\text { and allows them to decide how to accomplish them }\end{array}$ & $\begin{array}{c}19 \\
(5)\end{array}$ & $71(18)$ & $201(52)$ & $98(25)$ & $389(100)$ \\
$\begin{array}{l}\text { My leader makes sure staff are aware of, and } \\
\text { understand, all organisation policies and procedures }\end{array}$ & $123(32)$ & $181(47)$ & $\begin{array}{c}67 \\
(17)\end{array}$ & $\begin{array}{c}18 \\
(5)\end{array}$ & $389(100)$
\end{tabular}


table 1 cont ...

\begin{tabular}{|c|c|c|c|c|c|}
\hline Perceptions & $\begin{array}{l}\text { Strongly } \\
\text { agreed } \\
(\%)\end{array}$ & $\begin{array}{l}\text { Agreed } \\
\text { (\%) }\end{array}$ & $\begin{array}{l}\text { Disagreed } \\
(\%)\end{array}$ & $\begin{array}{c}\text { Strongly } \\
\text { disagreed } \\
(\%)\end{array}$ & Total (\%) \\
\hline $\begin{array}{l}\text { My leader recognises staff's achievements with } \\
\text { encouragement and support }\end{array}$ & $36(9.3)$ & $\begin{array}{c}114 \\
(29.3)\end{array}$ & $148(38)$ & $91(23.4)$ & $389(100)$ \\
\hline $\begin{array}{l}\text { My leader discusses any organisational or policy } \\
\text { changes with staff prior to taking action }\end{array}$ & $122(31)$ & $197(51)$ & $\begin{array}{c}53 \\
(14)\end{array}$ & $\begin{array}{l}17 \\
(4)\end{array}$ & $389(100)$ \\
\hline $\begin{array}{l}\text { My leader demonstrates each task involved in doing } \\
\text { the job }\end{array}$ & $\begin{array}{l}23 \\
(6)\end{array}$ & $41(11)$ & $212(54)$ & $113(29)$ & $389(100)$ \\
\hline $\begin{array}{l}\text { My leader avoids making judgements or premature } \\
\text { evaluation of ideas or suggestions }\end{array}$ & $\begin{array}{l}10 \\
(3)\end{array}$ & 73 (19) & $231(59)$ & 75 (19) & $389(100)$ \\
\hline $\begin{array}{l}\text { My leader asks staff to think ahead and develop } \\
\text { long-term plans for their areas }\end{array}$ & $56(14.4)$ & $\begin{array}{c}91 \\
(23.4)\end{array}$ & 173 (44.5) & 69 (17.7) & $389(100)$ \\
\hline $\begin{array}{l}\text { My leader sets down performance standards for } \\
\text { each aspect of my staff's job }\end{array}$ & $110(28)$ & $182(47)$ & $\begin{array}{c}73 \\
(19)\end{array}$ & $\begin{array}{l}24 \\
(6)\end{array}$ & $389(100)$ \\
\hline $\begin{array}{l}\text { My leader explains the benefits of achieving their } \\
\text { work goals to staff }\end{array}$ & $129(33)$ & 149 (38) & $\begin{array}{c}73 \\
(19)\end{array}$ & 38 (10) & $389(100)$ \\
\hline $\begin{array}{l}\text { My leader rotates the role of team briefer among the } \\
\text { staff }\end{array}$ & $45(12)$ & $99(25)$ & $129(33)$ & $116(30)$ & $389(100)$ \\
\hline $\begin{array}{l}\text { My leader emphasizes the importance of quality but } \\
\text { allows staff to establish the control standards }\end{array}$ & $14(4)$ & $82(21)$ & $199(51)$ & $94(24)$ & $389(100)$ \\
\hline $\begin{array}{l}\text { My leader provides staff with the time and resources } \\
\text { to pursue developmental objectives }\end{array}$ & $19(5)$ & $46(12)$ & $281(72)$ & $43(11)$ & $389(100)$ \\
\hline $\begin{array}{l}\text { My leader expect staff to create their own goals and } \\
\text { objectives and submit them to him in finished form }\end{array}$ & $-(-)$ & $17(4)$ & $209(54)$ & $163(42)$ & $389(100)$ \\
\hline $\begin{array}{l}\text { My leader focuses on opportunities and not } \\
\text { problems }\end{array}$ & $53(14)$ & $153(39)$ & $129(33)$ & $54(14)$ & $389(100)$ \\
\hline $\begin{array}{l}\text { My leader avoids evaluating problems and concerns } \\
\text { as they are discussed }\end{array}$ & $24(6)$ & $65(17)$ & $166(43)$ & $134(34)$ & $389(100)$ \\
\hline $\begin{array}{l}\text { Transactional type of leadership is in use in your } \\
\text { company }\end{array}$ & $129(33)$ & $149(38)$ & $\begin{array}{c}73 \\
(19)\end{array}$ & $38(10)$ & $389(100)$ \\
\hline $\begin{array}{l}\text { Transformational type of leadership is in use in your } \\
\text { company }\end{array}$ & $\begin{array}{c}73 \\
(19)\end{array}$ & $38(10)$ & $129(33)$ & $149(38)$ & $389(100)$ \\
\hline $\begin{array}{l}\text { Laissez-faire type of leadership is in use in your } \\
\text { company }\end{array}$ & $0(0)$ & $0(0)$ & $134(34)$ & $255(66)$ & $389(100)$ \\
\hline
\end{tabular}

Table 2: Variation in leadership styles in the oil and gas servicing companies in the study area

\begin{tabular}{cccc} 
Hypotheses & Variable & Results of statistics & Remark \\
1 & Leadership styles & $\mathrm{F}=343.8 \& \mathrm{p}=1.0>0.05$ & ${\text { Retain } \mathrm{H}_{0}}$ \\
\hline
\end{tabular}

\section{Discussion}

The main purpose of Occupational Health and Safety in the workplace is accident prevention. ${ }^{2,3,4}$ Accident avoidance is characterized at identifying the things that could go wrong and prevent it or at least the consequences there from. ${ }^{8}$ Therefore, identifying whether the leadership styles are good to ensure safety in the oil and gas servicing firms is a timely intervention, in realizing accident reduction in industries.

Generally, in this study it was established that, leaders checked staff work on a regular basis to assess their progress and learning, which showed that monitoring was frequent in the oil and gas companies. This finding was consistent with a similar study conducted earlier. ${ }^{1}$ However, it was in contrast to a study, which established that the monitoring in the oil industries were superficial, aimed at passing integrity tests alone and also explained of not having safety guarantee with the visibly expressed monitoring. ${ }^{2}$ Findings also revealed that leaders hardly appointed staff into task groups to action policies affecting them, and leaders did not provide staff with clear responsibilities implying that the workers were not allowed to use or apply their 
individual intuition, and this possibly created a slack in the participation of workers. This was consistent with the findings in an earlier report. ${ }^{4}$ It however, buttressed the earlier warning by a study, which hitherto warned that, efforts must be made to carry workers along with company policies, let them advice when necessary and by extension make them co-managers, adding that when laid down procedures are failing; the workers are less likely to apply alternative safety application, thereby leading to accidents, if stereotyped. $4,8,10$

Furthermore, the study identified that, leaders made sure staff were aware of, and understood all organization policies and procedures. Therefore, the accidents occurred might be related to workers as they were not allowed to change contingencies when there was urgency, or that the emotional intelligence of the workers had been affected using poor leadership styles. Achievements were not recognized, which might be demoralizing to the workers. As mentioned in an earlier study, acknowledgement of workers intelligence and progress not only built workers confidence, but it also improved work place safety. ${ }^{7,18}$

Changes in policies were discussed with workers before they were carried out. However, the input of the workers meant nothing; rather most of those discussions were held for communication and application purposes. Furthermore, leaders made judgements or evaluation of new ideas hastily. According to previous studies, all these types of approach to leadership, particularly, in highly hazardous industries are a recipe for disaster. 2,11 This study showed that leadership characteristics were same across the companies (oil and gas servicing firms) which was in contrast to an earlier study which found that, the national companies were different in leadership approach compared with the international companies. 6,7

Generally, in terms of approaches to leadership, it showed that the transactional type was in use which made the study be in tandem with earlier findings. ${ }^{2,11}$ Transactional leadership style does not generate creativity; rather, it ensures that employees understand their tasks while removing barriers to the desired goals. ${ }^{1,9}$ Transactional leadership uses contingent reinforcement; positive contingent rewards are used to achieve desired behavior, while negative action or sanctions are used where the desired behaviour is not present. Transactional leadership is more of a managerial approach to leadership within the public organization. In leadership, leaders ought to adopt transactional attitudes only when there are failures, deviations, and breakdowns. ${ }^{1}$ In other words, it does not generate any creativity nor allow staff to see themselves as co-managers of the companies, thus resulting in poor safety practices in the oil and gas servicing firms.

\section{Conclusion}

This study assessed leadership style and safety in oil and gas servicing firms in Portharcourt metropolis, Nigeria and establish that there was poor leadership in the oil and gas servicing firms. The leadership style identified was the transactional type and showed that the attitudes of the leaders created unsettling conditions in workers which made for some inaction by them, resulting in risky behaviours in the companies. It is dangerous for such conditions to prevail for long periods in the industry, considering the delicate nature of the oil industry and how devastating its accidents are. This study therefore concluded that there should be a review in the leadership characteristics and approach in the oil and gas industry, so as to improve on the safety behavior of workers.

\section{Recommendations}

The following are recommendations from the findings of this study:

a) The study recommended a review of the leadership approaches adopted for oil and gas workers in the area, by improving on the worker/leader relationships.

b) Promotions and appraisals should be based on a recognition of input rather than favouritism

c) Staff should be allowed to improvise in emergency conditions because a lot could go wrong when workers are forced to be placed in such situations due to outlined work procedures

d) Staff recharge and engagements should be based on merit rather than on informal relationships

\section{Limitation of the study}

The limitation of this study is there needs to be statistically significant on relationships and effects of leadership styles on safety efficiency.

\section{Conflict of interest}

The author declare no conflict of interest with regards to this article, authorship, and/or publication. 


\section{References}

1. Andrews R, Van de Walle S. New public management and citizens' perceptions of local service efficiency, responsiveness, equity and effectiveness. Public Management Review. 2013; 15(5): 762-83. doi:10.1080/14719037.2012.725757

2. Antonakis J, House RJ. The full-range leadership theory: The way forward. In Avolio, BJ and Yammarino, FJ (Eds.). Transformational and charismatic leadership: The road ahead. Bingley, UK: Emerald Group 2013.

3. Adanri AA. The relationship between Nigerian local government administrative leadership styles and organizational outcomes. (Doctoral dissertation). Retrieved from: http://scholarworks.waldenu.edu/cgi/ viewcontent.cgi?article $=3614 \&$ context=dissertatio ns, 2016.

4. Bara KB, Chandrakantan S, Hassan A. Inclusive Leadership, Safety Climate and Safety Behaviour: A Proposed Framework. International Journal of Academic Research in Business and Social Sciences. 2017; 7(2): 19-28. ISSN: 2222-6990

5. Wu C, Fang D, Li N. Roles of owners' leadership in construction safety: The case of high-speed railway construction projects in China. International Journal of Project Management. 2015; 33(8): 1665-79.

6. Barbaranelli C, Petitta L, Probst TM. Does safety climate predict safety performance in Italy and the USA?: Cross-cultural validation of a theoretical model of safety climate. Accident Analysis \& Prevention. 2015; 77: 35-44

7. Chiles E. Expectations of job satisfaction based on three common leadership styles (Doctoral dissertation). 2015. Retrieved from http:// scholarworks.waldenu.edu/cgi/viewcontent.cgi?articl $e=1458$ \& context $=$ dissertations.

8. Clarke S. Safety leadership: A meta-analytic review of transformational and transactional leadership styles as antecedents of safety behaviours. Journal of Occupational and Organizational Psychology. 2013; 86(1): 22-49.

9. Conchie SM. Transformational leadership, intrinsic motivation, and trust: A moderated-mediated model of workplace safety. Journal of Occupational Health Psychology. 2013; 18(2): 198-210.

10. Dahl, O., Olsen, E. Safety compliance on offshore platforms: A multi-sample survey on the role of perceived leadership involvement and work climate. Safety Science, 2013; 54:17-26.

11. Birkeland NM, Eid J, Mearns K, Larsson G. Authentic leadership and its relationship with risk perception and safety climate. Leadership \& Organization Development Journal. 2013; 34(4): 308-25.
12. Zohar D, Huang $\mathrm{YH}$, Lee J, Robertson M. A mediation model linking dispatcher leadership and work ownership with safety climate as predictors of truck driver safety performance. Accident Analysis \& Prevention. 2014; 62: 17-25.

13. Panuwatwanich K, Al-Haadir S, Stewart RA. Influence of safety motivation and climate on safety behaviour and outcomes: evidence from the Saudi Arabian construction industry. International Journal of Occupational Safety and Ergonomics. 2016; 31:131.

14. Tholen SL, Pousette A, Torner M. Causal relations between psychosocial conditions, safety climate and safety behaviour. A multi-level investigation. Safety Science. 2013; 55:62-9.

15. Newaz MT, Davis P, Jefferies M, Pillay M. The Psychological Contract of Safety: The Missing Link between Safety Climate and Safety Behaviour in Construction Sites. Accident Analysis \& Prevention. 2016; 67 (2): 140-67.

16. Onorato M. Transformational leadership style in the educational sector: An empirical study of corporate managers and educational leaders. Academy of Educational Leadership Journal. 2013; 17(1): 33-52.

17. Martinez-Corcoles M, Gracia FJ, Tomas, I, Peiro JM, Schobel M. Empowering team leadership and safety performance in nuclear power plants: A multilevel approach. Safety Science. 2013; 51(1): 293-301.

18. Probst TM, Jiang L. Mitigating Physiological Responses to Layoff Threat: An Experimental Test of the Efficacy of Two Coping Interventions. International Journal of Environmental Research and Public Health. 2016; 13(3): 338-52.

19. Amanchukwu, RN., Stanley, GJ., Ololube, NP. A review of leadership theories, principles and styles and their relevance to educational management. Management, 2015; 5(1): 6-14. doi:10.5923.j.mm.20150501.02.html

20. Freeborough R, Patterson K. Exploring the effect of transformational leadership on nonprofit leader engagement. Servant Leadership: Theory and Practice. 2015; 2(1):

49-70. Available from: https://pdfs.semanticscholar. org/2b10/ .pdf

21. Campbell JW. Red tape and transformational leadership: an organizational echelons perspective. Journal of Organizational Change Management. 2017; O(1):76-90. doi:10.1108/JOCM-01-20160004109

22. Caillier JG. Toward a better understanding of the relationship between transformational leadership, public service motivation, mission valence, and employee performance: A preliminary study. Public Personnel Management. 2014; 43(2): 218-39. doi:10.1177/0091026014528478 